\title{
Inventory and assessment of geosites to stimulate regional sustainable management: the northern coast of the state of São Paulo, Brazil
}

\author{
MARIA DA GLÓRIA M. GARCIA, ELIANE A. DEL LAMA, LUCELENE MARTINS, \\ CARLOS EDUARDO M. MAZOCA and CHRISTINE L.M. BOUROTTE
}

\author{
Núcleo de Apoio à Pesquisa em Patrimônio Geológico e Geoturismo (GeoHereditas), Instituto de \\ Geociências, Universidade de São Paulo, Rua do Lago, 562, 05508-080 São Paulo, SP, Brazil \\ Manuscript received on May 23, 2018; accepted for publication on August 10, 2018
}

\begin{abstract}
How to cite: GARCIA MGM, DEL LAMA EA, MARTINS L, MAZOCA CEM AND BOUROTTE CLM. 2019. Inventory and assessment of geosites to stimulate regional sustainable management: the northern coast of the state of São Paulo, Brazil. An Acad Bras Cienc 91: e20180514. DOI 10.1590/0001-3765201920180514.

Abstract: The reviewed and integrated geoheritage inventory of the northern coast of the state of São Paulo, Brazil, resulted in 43 geosites distributed in eight geological frameworks. The selected geosites are representative of a geological history from the Neoproterozoic (Brasiliano-Pan African Cycle) to the recent, covering a minimum 700-Ma timespan. Considering the dynamic character of geoheritage inventories, the results presented in this work were based on previous local, town-based surveys, which were reviewed under the light of new geological data and geoconservation methods. Both qualitative and quantitative geosites assessments were used to discuss their geological representativeness and relevance, as well as legal aspects regarding protection and perspectives for future use. This resulted in a detailed inventory that reflects the current geological knowledge in the northern coast of the state of São Paulo, and may be used to make a general diagnosis of the scientific value, state of conservation, risk of degradation and potential use of the geoheritage. Moreover, it reinforces the importance of locally- and regionally-relevant sites for sustainable land management using geoheritage and to direct the decisions related to the conservation and use of this abiotic part of nature in the region.
\end{abstract}

Key words: Brazil, São Paulo, geological heritage, geoheritage management, inventory, Public policies.

\section{INTRODUCTION}

Many of the most significant Brazilian natural attractions, such as the Iguaçu Falls in Foz do Iguaçu or the Sugar Loaf in Rio de Janeiro, constitute remarkable expressions of the geological processes that acted out in the formation of the country's natural scenery. Besides geological relevance, their use as key pieces in national tourism strategies

Correspondence to: Maria da Glória Motta Garcia

E-mail:mgmgarcia@usp.br

ORCid: https://orcid.org/0000-0002-9846-1870 shows that geological heritage may be highly useful in the sustainable promotion of the territory and in the benefit of the population.

Both sites mentioned above are included in the UNESCO World Heritages Sites and are described in a three-volume book edited by the Brazilian Commission of Geological and Palaeobiological Sites (SIGEP), created in 1997 as a result of the Global Geosites Project (Wimbledon 1996) in Brazil. The SIGEP's methodology is based on adhoc proposals, in which geoscientists of several knowledge areas make suggestions about sites 
included in their research works or in known areas. A commission composed of experts evaluates the proposal and, in order to justify its inclusion in a national database, the researcher is invited to write a paper about the scientific relevance of the site. Despite its pioneer and important role, the SIGEP has been discontinued since 2012 and new proposals are not currently accepted.

At the national level, some initiatives involving inventories deserve special mention, such as the Geodiversity and the Geopark projects, of the Geological Survey of Brazil (CPRM). In the state of São Paulo the first initiative to consider geoconservation strategies for geological heritage was the Geological Monuments Project, of the Geological Institute, Department of the Environment (IG/SMA) and, more recently, the inventory of the state of São Paulo was performed characterizing 142 geosites (Garcia et al. 2018). Other local initiatives and a general overview on geoheritage inventories in Brazil may be found in Romão and Garcia (2017).

Geoheritage inventories can be done at different scales, and the choice of a certain geosite depends on the scale and the objectives of the work. At global scale, the recognition of sites with 'outstanding universal relevance' that represent global geological history had its roots in the Global Geosites Project (Wimbledon 1996, 2011, Díaz-Martínez et al. 2016). Although formally discontinued, several countries, especially in Europe, have used its methodology to carry out their national inventories. Examples of practical developments of national systematic inventories may be found in several countries, like Portugal (Brilha et al. 2010, 2013, Brilha and Pereira 2014), Spain (Garcia-Cortés et al. 2001, GarcíaCortés and Carcavilla-Úrqui 2009, Carcavilla et al. 2009) and United Kingdom (Wimbledon et al. 1995, Ellis 2011) - Table I. Other countries, like Switzerland (Berger et al. 2008, 2011, Reynard 2013), Poland (Alexandrowicz and Kozlowski
1999), Italy (ISPRA 2018), France (De Wever et al. 2015), among others, have also carried out their national inventories in recent years and the results are gradually being disseminated.

The facts above show that an inventory alone is not an end, but it should serve as a basis for any future plan related to geoheritage (Cendrero Uceda 2000, Wimbledon 2011). The systematic, detailed knowledge of the geology and geological heritage in a given region is important because it allows a diagnosis of the geological sites available, either for scientific, tourism or educational purposes. Taking the "conservation + use" binomial as the main goal of geoconservation initiatives, the more complete is the knowledge, the more effective its management may be.

In this sense, this research presents the integrated and reviewed results of the geoheritage inventory in the northern coast of São Paulo State, Brazil, which uses local- to internationally relevant geosites as representative record of the geological history of this area. Our broad geosites' survey is part of a strategy that also includes the identification of geodiversity sites (Arruda et al. 2017b) in order to have a solid diagnosis of the sites of geological interest in the area. Our intention is that these data will be used to guide actions regarding: i) Conservation of geological heritage as the memory of the Earth in Brazil - which involves both its legal protection and its inclusion in territorial planning strategies; ii) Popularization of geoscience - which also denotes a contribution to the general education of the population; and iii) Inclusion of geosciences in tourism and educational activities - which may be part of regional sustainable development plans.

\section{THE IMPORTANCE OF LOCAL INVENTORIES}

Because of their scale, national inventories include geosites that are primarily related to national or state frameworks, which may limit the registers of relevant places. Moreover, it can also exclude many 
TABLE I

Practical developments related to the use of geosites' data obtained from geoheritage national inventories.

Country Period Developments from the inventory

\begin{tabular}{cccc}
\hline $\begin{array}{c}\text { United } \\
\text { Kingdom }\end{array}$ & Since $1977 \begin{array}{l}\text { Results being published in a series of } 45 \text { volumes. The sites selected - GCR sites - form the basis } \\
\text { of statutory geological and geomorphological site conservation in Britain. The sites also serve as } \\
\text { the basis for so-called "Geodiversity Action Plans" and the "Geodiversity Charters", which define } \\
\text { actions to conserve, enhance and promote the geodiversity in several scales. }\end{array}$ \\
Spain $\quad$ Since 1978 & $\begin{array}{l}\text { Especially in the last fifteen years, the increasing integration of geoconservation into scientific } \\
\text { and social themes, associated with the active participation of Spanish geological societies, has } \\
\text { greatly influenced the legal system, as is the case of Law 42/2007, which includes conservation of } \\
\text { geological heritage as one of its bases. }\end{array}$ \\
Portugal & Since $2007 \quad \begin{array}{l}\text { Adaptation of nature conservation laws to include concepts such as geosite and geological } \\
\text { heritage (Decree-Law 142/2008), directly influencing management and making issues related to } \\
\text { Geoconservation be addressed formally from basic to postgraduate. }\end{array}$ \\
\hline
\end{tabular}

sites that, although lacking scientific relevance, may be important in terms of local policies. The recognition of places of geological interest with local relevance is of prime importance because, although most of these sites are not suitable for a national inventory or protection, they might be fundamental to stimulate the participation of people and to increase the self-esteem of local communities. Detailed knowledge of these sites also launches alternatives for different kinds of management and use, depending on the property regime, their relevance regarding the size of the area, and potential uses.

One of the most emblematic examples of the use of locally-relevant geological sites is in the United Kingdom, where more than 3,000 sites have been inventoried, being nearly all of these Sites of Special Scientific Interest (SSSI) and statutorily protected. However, in order to promote regionally or locally representative sites, the designation of Regionally Important Geological and Geomorphological Sites (RIGS) was created (Nature Conservation Council 1990). RIGS constitute sites that, although not legally protected, are either regionally or locally representative and part of a whole sustainable, conservation plan. Both SSSI and RIGs serve as bases for the so-called "Geodiversity Action Plans" and "Geodiversity Charters" (Scottish Geodiversity Forum 2013, English Geodiversity Forum 2014) which define actions to conserve, to enhance and to promote geological sites of a particular area, based on governmental organization in various fields. These are intended to provide common guidelines for actions involving these sites, fostering partnerships, and influencing public authorities and funding agencies (Burek and Potter 2003, 2006, DEFRA 2006). In the last fifteen years, these strategies have been guiding the conservation of geologically important sites in the United Kingdom.

In Spain, 3,154 sites of geological interest have already been inventoried, being these sites related to distinct bases, such as the older and the current official IGME (Geological Survey of Spain) inventory, the official inventories of the autonomous communities and those with local importance (IGME 2018). Although not all these sites are included in the national inventory, their recognition has been important to boost regional management using geoheritage (Fuertes-Gutiérrez and Fernández-Martínez 2010, Oms et al. 2012, Pellitero et al. 2011, Martín-Duque et al. 2012). 
Inventories in geoparks and in protected areas also are examples of local inventories that play an important role in territorial management, such as in Portugal, where the geoheritage inventory of Arouca (Rocha 2008) has been the starting point for the Arouca Geopark and local inventories regarding specific municipalities of the Naturtejo Geopark are essential for the complete knowledge of the territory (Neto de Carvalho et al. 2009, Vilas Boas et al. 2015). Aspiring geopark projects are also based on geoheritage inventories, such as the Viana do Castelo municipality (Carvalhido et al. 2016).

\section{MATERIALS AND METHODS}

The northern coast of the State of São Paulo, Brazil, extends in NE-SW direction for almost $400 \mathrm{~km}$ (Figure 1) and has been the focus of local inventory works since 2011 (Garcia 2012). These inventories are based on four municipalities that compound the region and include three master's dissertations in Ilhabela (Prochoroff 2014), São Sebastião (Reverte 2014, Reverte and Garcia 2016a, b) and Ubatuba (Santos 2014), and a doctoral thesis involving both the inventory of Caraguatatuba and a geotourism mapguide for the whole northern coast (Arruda 2017, Arruda et al. 2017a). Complete descriptions of the sites and of the inventory methods may be found in these research works. As direct products of these local inventories, 35 geosites were originally selected: 10 in Ubatuba, 7 in Caraguatatuba, 9 in São Sebastião, and 9 in Ilhabela, part of which were included in the geoheritage inventory for the state of São Paulo (Garcia et al. 2018). The strategy used was conceived from the methodology described in Brilha (2005) for smaller study areas. Data collection was based on the following steps: i) literature review; ii) consulting with experts in different areas of geosciences; iii) pre-selection of potential geosites; iv) field work; and v) final definition of geosites. These steps are part of a strategy that has become classic for Geoconservation as a science (Henriques et al. 2011).

In this review, 43 geosites distributed in 8 geological frameworks were defined (Figure 1). The main parameter that directed the choice of the sites was their representativeness, which aims to reliably express the relationship between geosite's significance and its role in the regional geological context. The selection of the geosites was guided on the basis on the following considerations:

1) In order to select sites that would represent the geological materials and processes, geomorphological units and events that constitute the record of the geological history of the area, we followed the method described in Mucivuna et al. (2015), with analyses of geological maps and satellite images obtained from Google Earth ${ }^{\circledR}$ to identify the main litostratigraphic units and regional structures. The main geological basis was the Geological Map of the State of São Paulo, developed by the Geological Survey of Brazil - CPRM - in scale 1:750,000 (Perrotta et al. 2005), with changes made from recent geological mapping (Meira 2014, Barreto 2016, Pires 2017);

2) The selection of the geosites in the original works was based on the evolution of the West Gondwana Supercontinent (including both previous and later features and events) to the present. Although described in chronological order, the geosites were not formally distributed among previously defined geological frameworks. Therefore, on the basis of the main units and features in the area, as well as the main geological events, in this review we define eight geological frameworks that intend to summarize the geological history of the region;

3) The original inventories of three of the municipalities (Ubatuba, São Sebastião and Ilhabela) were finished before 2014 and the inventory of Caraguatatuba in 2015. After 


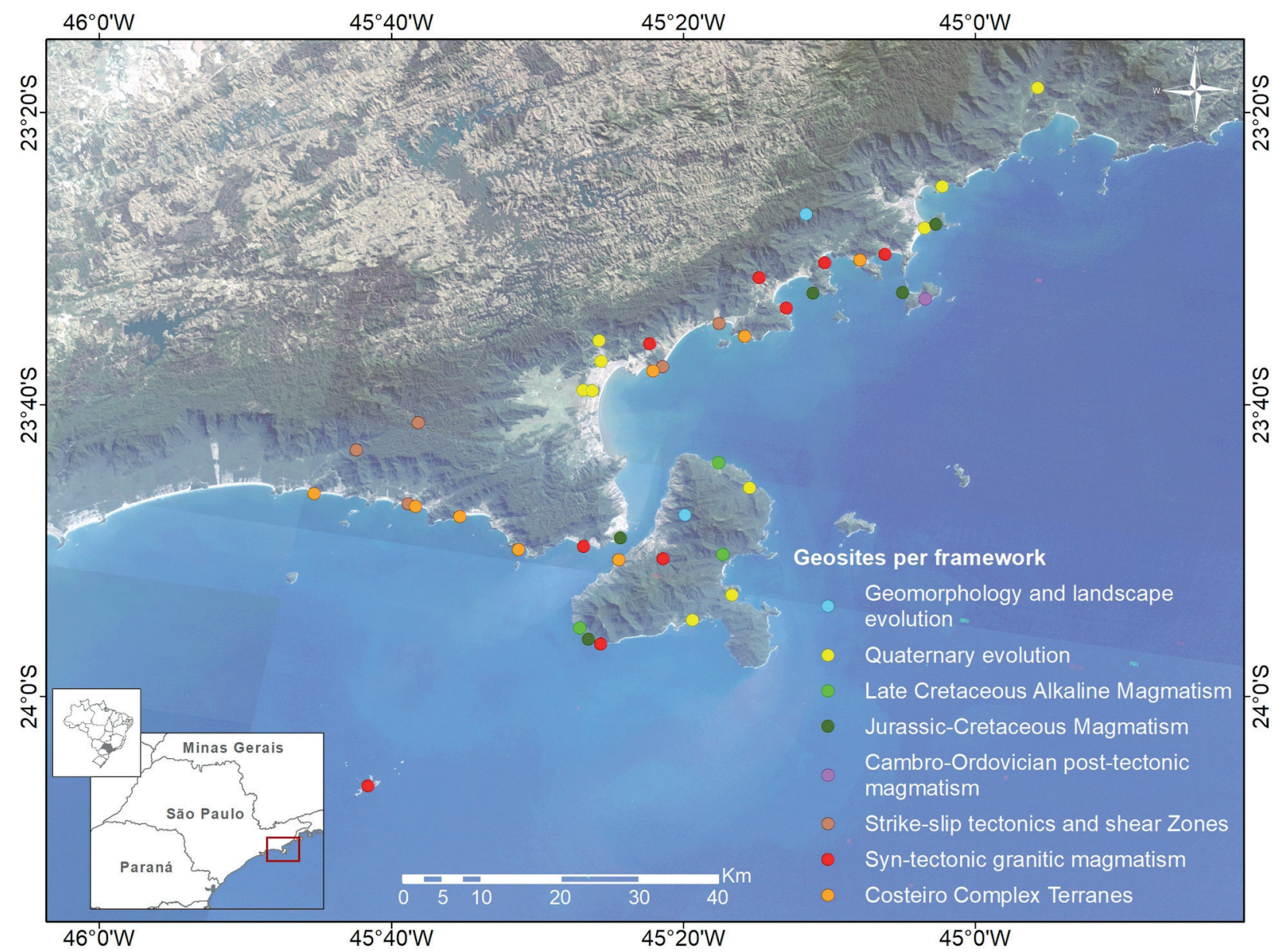

Figure 1 - Map of the northern coast of São Paulo State showing the location of the geosites according to each geological framework.

that, the results related to the inventory of the State of São Paulo (Garcia et al. 2018) were launched, and additional geosites in the area were incorporated by the coordinators. These sites have been included in this review;

4) Recent research works have been carried out (Meira 2014, Meira et al. 2015, Barreto 2016, Timich et al. 2016, Pires 2017, Rodrigues 2018), which provided new data to the present knowledge of the area. These works have allowed the definition of new geosites;

5) The present review was carried out on the basis of the conception of Brilha (2016), which defines as geosites only the scientifically relevant places (with or without other associated values) and as geodiversity sites those with mainly tourism or educational relevance. Therefore, some previously defined geosites have been now nominated as geodiversity sites, and vice-versa. A survey of the geodiversity sites carried out on the basis of previous surveys may be found in Arruda et al. (2017b);

6) A geosite name must contain short, but precise information about its content (and moreover, about its representativeness) and its location. Many of the geosites previously defined were named after the places where they are located, which does not reflect their content. In this review this aspect was readjusted; 
7) Finally, the main criteria used to select a specific geosite was the scientific relevance, which may be conveniently measured by the existence of specialized publications. Most of the sites selected have been, indeed, referred in peer-reviewed papers, book chapters, theses and dissertations. Some of the sites, however, do not appear as the focus of any publication, but constitute representative examples of regionally important geological units and/or of relationships between these units, as well as of features indicative of paleoenvironments, among others.

Table II presents a summary of the 43 geosites defined in this review. The results obtained reflect the current knowledge in the northern coast of the State of São Paulo and may be used to make a general diagnosis of the scientific value, state of conservation, risk of degradation and potential use of the geosites in the area.

\section{GEOSITES AS REPRESENTATIVE RECORD OF THE GEOLOGICAL EVOLUTION OF A REGION}

The selection of the geosites in the inventory was based mainly on a framework related to the amalgamation, evolution and fragmentation of the West Gondwana Supercontinent, as well as to later events and processes that culminated with the generation of the South Atlantic Ocean, the formation of the Serra do Mar Mountain Range and the coastal plains.

The regional organization of the landscapes in the studied area results from geological processes that have been active predominantly since the Neoproterozoic, during the Brasiliano-Pan African Cycle, related to the collision between the São Francisco Craton and other plates, microplates and/or island arcs with the Western Congo Craton, between 650-510 Ma (Schmitt et al. 2004, Heilbron et al. 2004, 2008, Tupinambá et al. 2012, Brito Neves et al. 2014). Alternative interpretations can be found in Meira et al. (2015). The geosites included in this item record the tangential tectonics related to the collision events, and collages that resulted in thrusting and folding from east-southeast to west-northwest (Figure 2a, b). It also includes the syntectonic granitic magmatism related to the thickening of the crust associated to the collisional episodes that caused widespread generation of melts, dated in the interval of 656-610 Ma (Alves et al. 2013, Heilbron et al. 2017) (Figure 2c, d).

Transpressive tectonics resulting from this collision resulted in the formation of a branch of NE-SW-oriented, mainly dextral strike-slip shear zones, which were later affected by several stages of reactivation (Figure 2e). Later, Cambro-Ordovician magmatism also occurred, related to post-collisional magmatism associated to the collapse after the Búzios Orogeny, the youngest convergent record in the Ribeira Belt. These granites are dated $\sim 500$ $\mathrm{Ma}$ (Figure 2f) and the known occurrence extends to the south of the studied area (Azevedo Sobrinho et al. 2011, Janasi et al. 2012). The orientation of the current coastline of South America is highly controlled by these Precambrian crustal structures.

In the Late Cretaceous ( $130 \mathrm{Ma})$, reactivation of the Brazilian Platform (Almeida 1969) was characterized by extensional processes related to the breakdown of the supercontinent Pangaea, the separation between South America and Africa, and the opening of the South Atlantic Ocean (Mohriak et al. 2008). Intense tholeiitic magmatism occurred associated with the early stages of these processes, giving origin to extensive flood basalt related to the Paraná-Etendeka Igneous Province and dyke swarms (Almeida et al. 1996, Garda and Schorscher 1996, Coutinho 2008) (Figure 3).

Later, Upper Cretaceous alkaline magmatism associated to alignments of alkaline plutons also occurred. In the region these are represented by the alkaline stocks of Ilhabela and some minor islands (Almeida 1983, Riccomini et al. 2005) - Figure 4. 


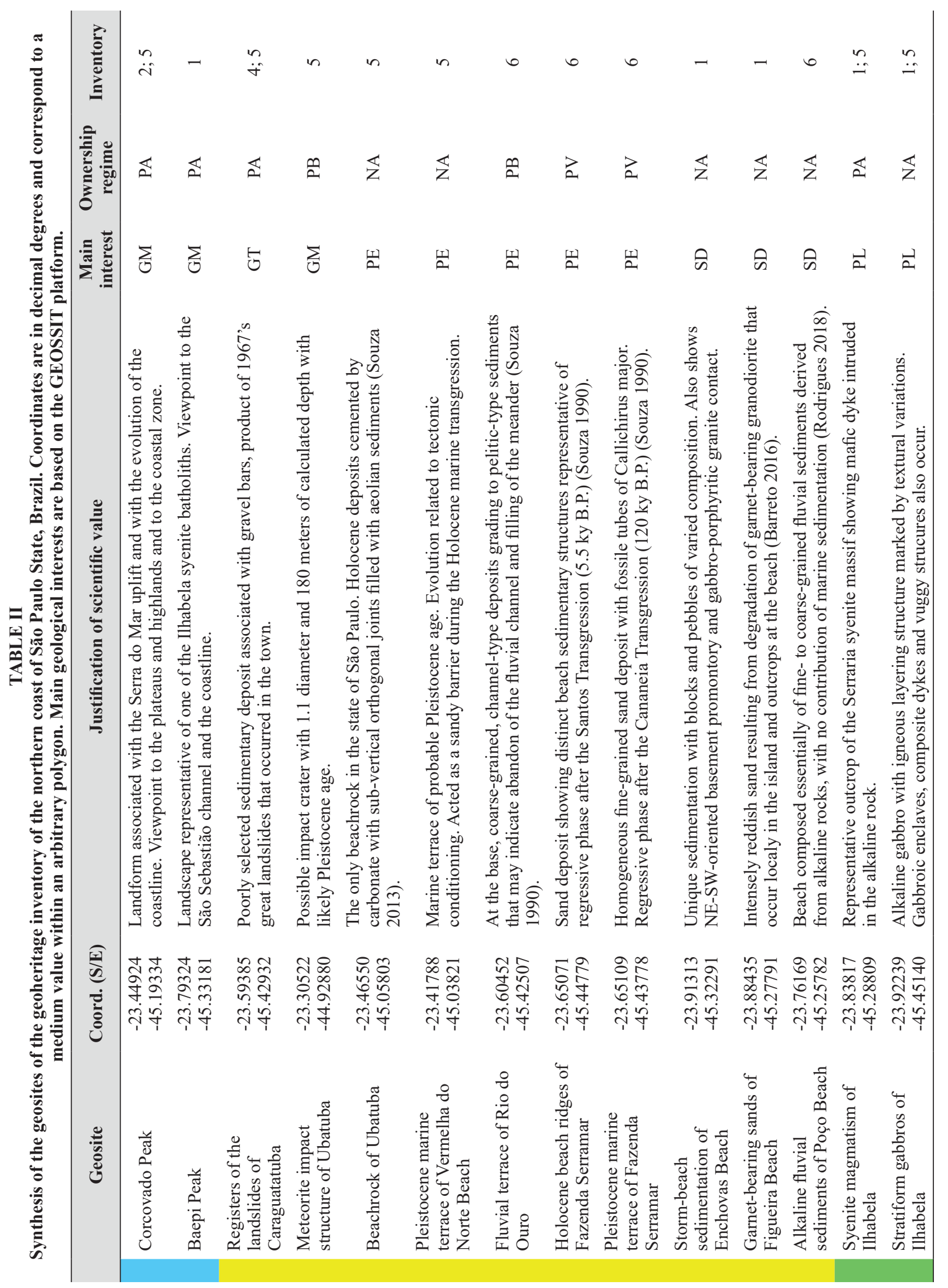




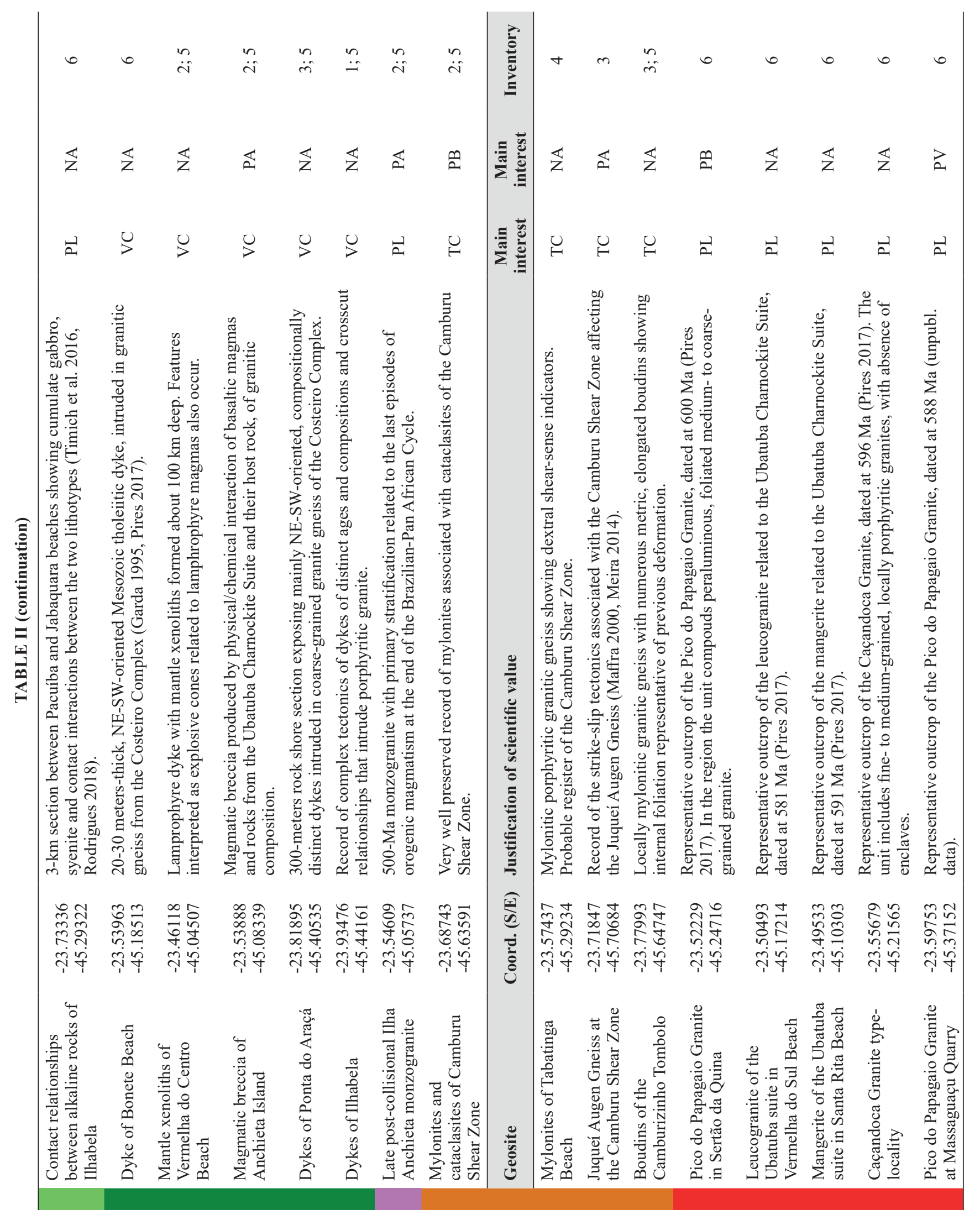




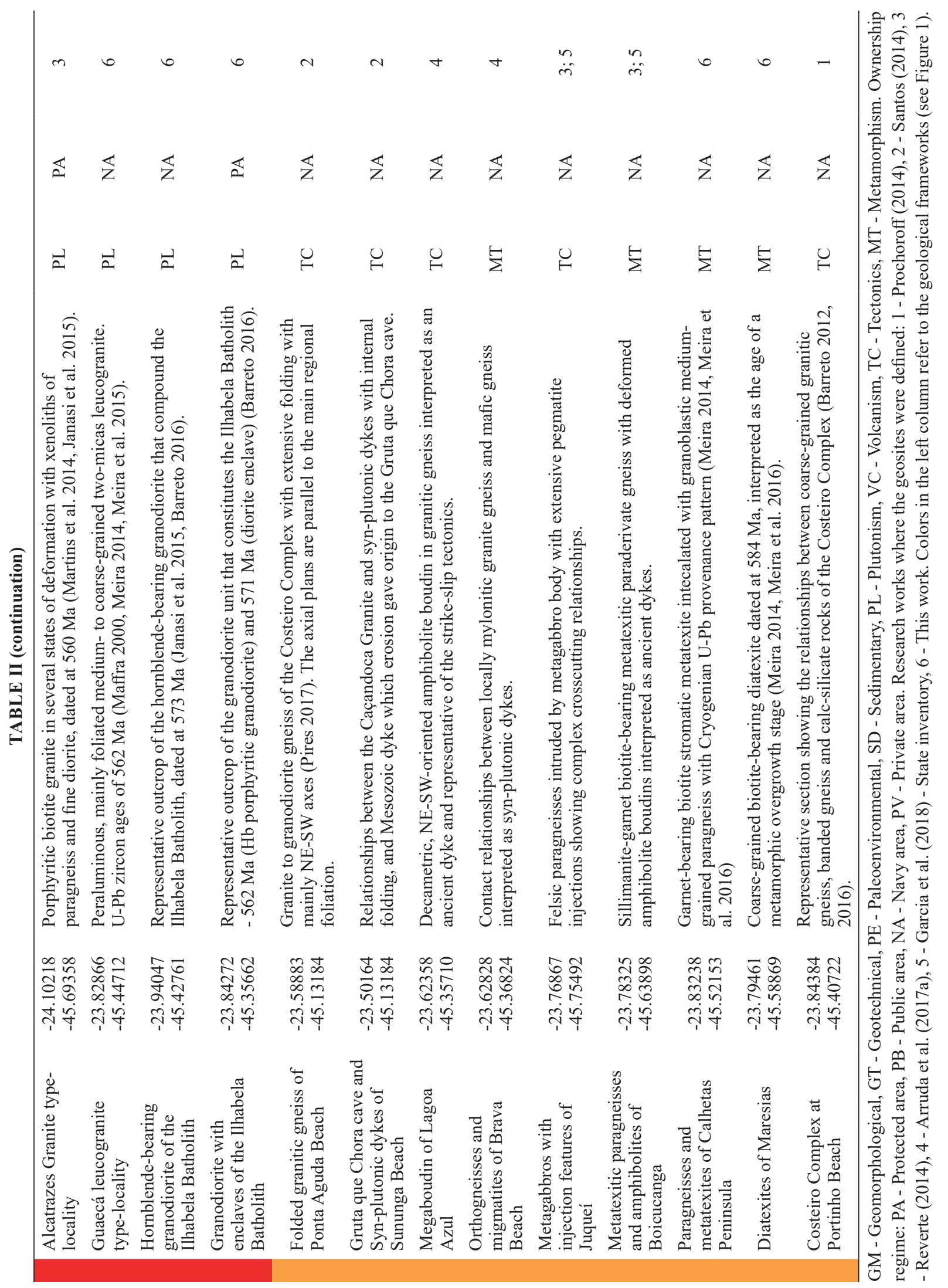



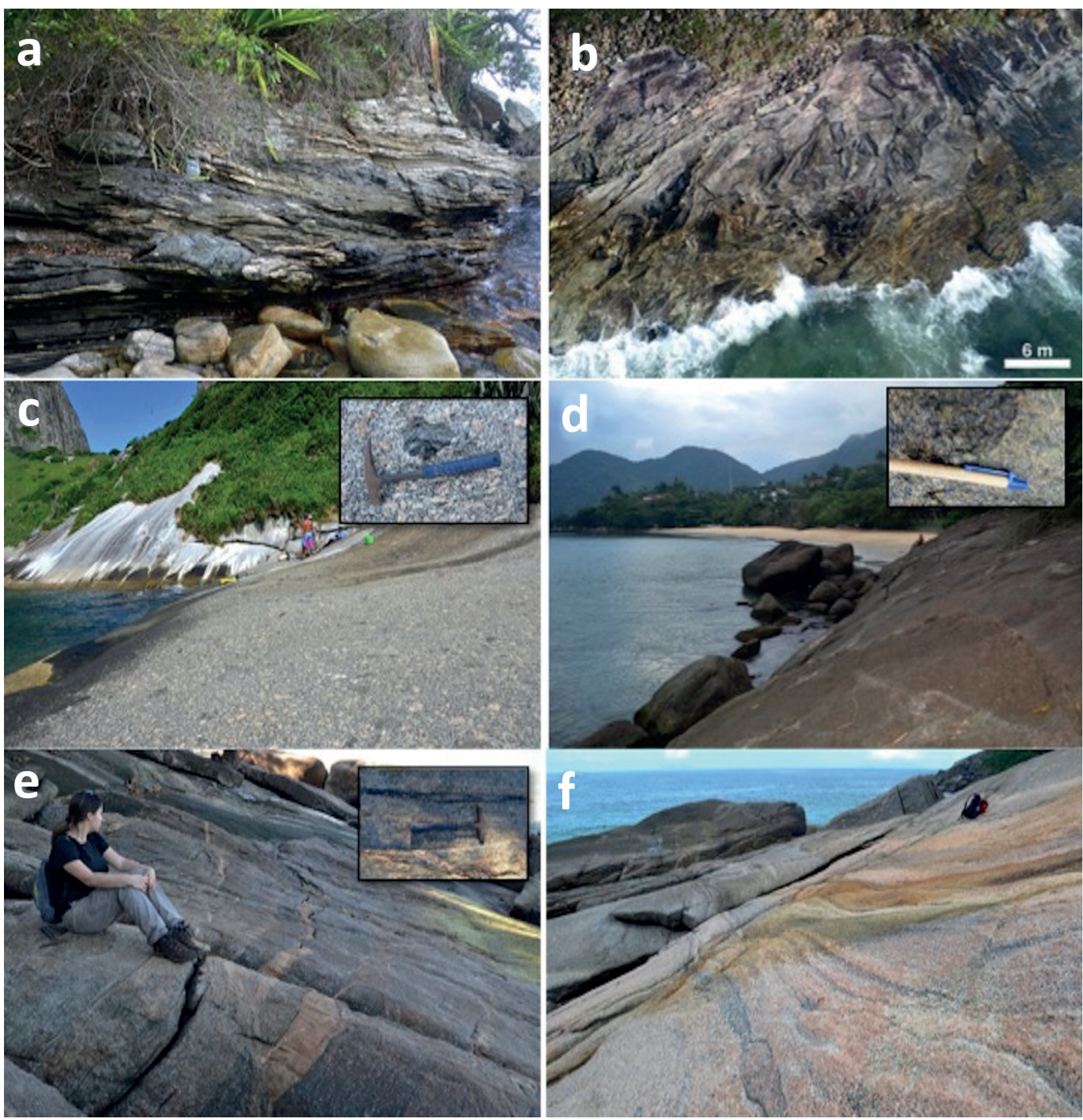

Figure 2 - Representative geosites of the geological frameworks (GF) related to the Brasiliano-Pan African Cycle (NeoproterozoicCambrian). GF Costeiro Complex Terranes: a) Geosite "Costeiro Complex at Portinho Beach". This site consists of a section showing complex relationships between lithotypes from the basement and calc-silicate rocks; b) Geosite "Metatexitic paragneisses and amphibolites of Boiçucanga". Sillimanite - garnet-bearing metatexitic biotite gneisses associated to amphibolite boudins; GF Syntectonic granitic magmatism: c) Geosite "Alcatrazes Granite type-locality". d) Geosite "Mangerite of the Ubatuba suite in Santa Rita Beach". Similar ages were obtained by other authors - 582 Ma - Janasi et al. (2015), Tassinari et al. (2008); GF Strikeslip tectonics and shear zones: e) Geosite "Mylonites of Tabatinga Beach and Tamanduá Island". An example of the strike-slip shear zones that result from the escape tectonics that gave origin to transpressive, linear domains in the Southeast of Brazil. Similar mylonitic foliations are observed both in the continent and in the island; GF Cambro-Ordovician post-tectonic magmatism: $\mathbf{f}$ ) Geosite "Ilha Anchieta Monzogranite". This 500-Ma monzogranite outcrop represents the collapse stage of the Brasiliano-Pan African Orogeny and shows pervasive igneous planar structures that represent primary layering. 

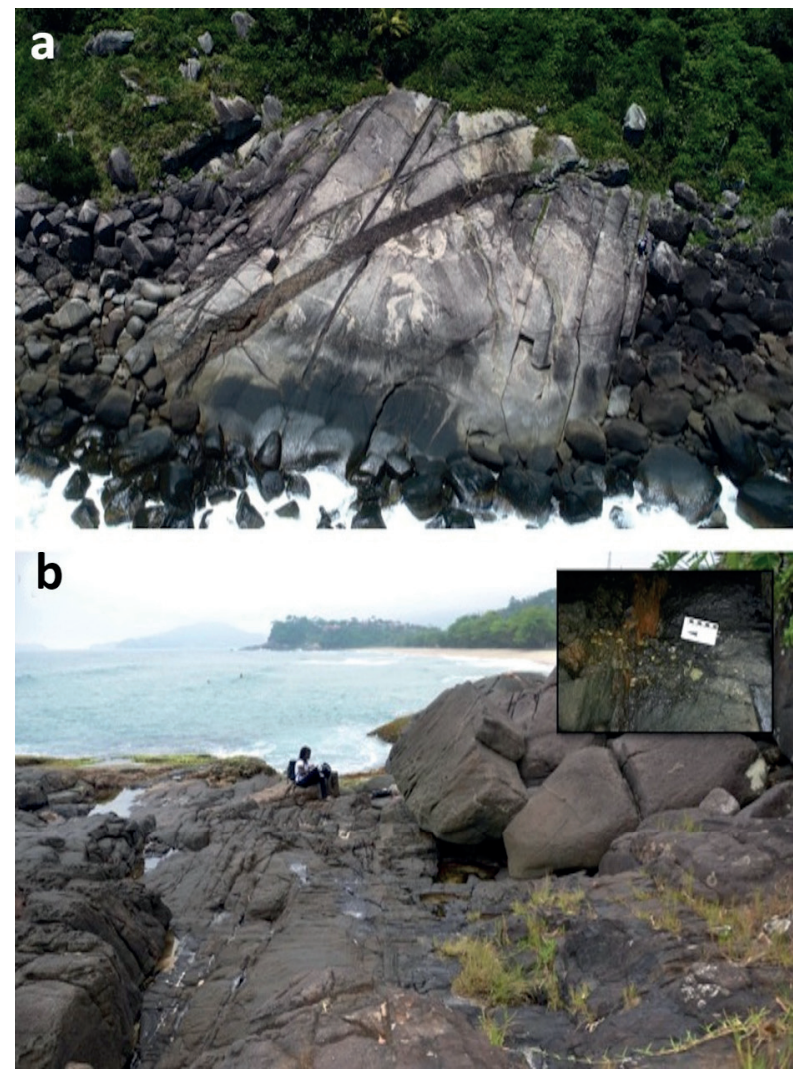

Figure 3 - Representative geosites related to the GF JurassicCretaceous magmatism. a) Geosite "Dykes of Ilhabela". An excellent example of the Jurassic-Cretaceous volcanic events associated to the first stages of Gondwana breakup. Granitic gneisses from the basement are crosscut by both lamprophyre and basic dykes that show important chronological information related to the stress field associated to the opening of the south Atlantic Ocean; b) Geosite "Mantle xenoliths of Vermelha do Centro Beach". Lamprophyre dyke with mantle xenoliths formed about $100 \mathrm{~km}$ deep. Features interpreted as explosive cones related to lamprophyre magmas also occur.

The sequence of events previously described consisted of geological, geomorphological, and climatic processes that controlled the evolution of the current coastal physiography. During the Quaternary, climatic variations and sea-level fluctuations gave origin to marine-beach deposits associated to both continental and transitiontype sediments (Suguio and Martin 1978), which compose coastal plains that vary from large ones, like the Caraguatatuba Plain, to small bays separated by rocky spurs of basement rock, forming
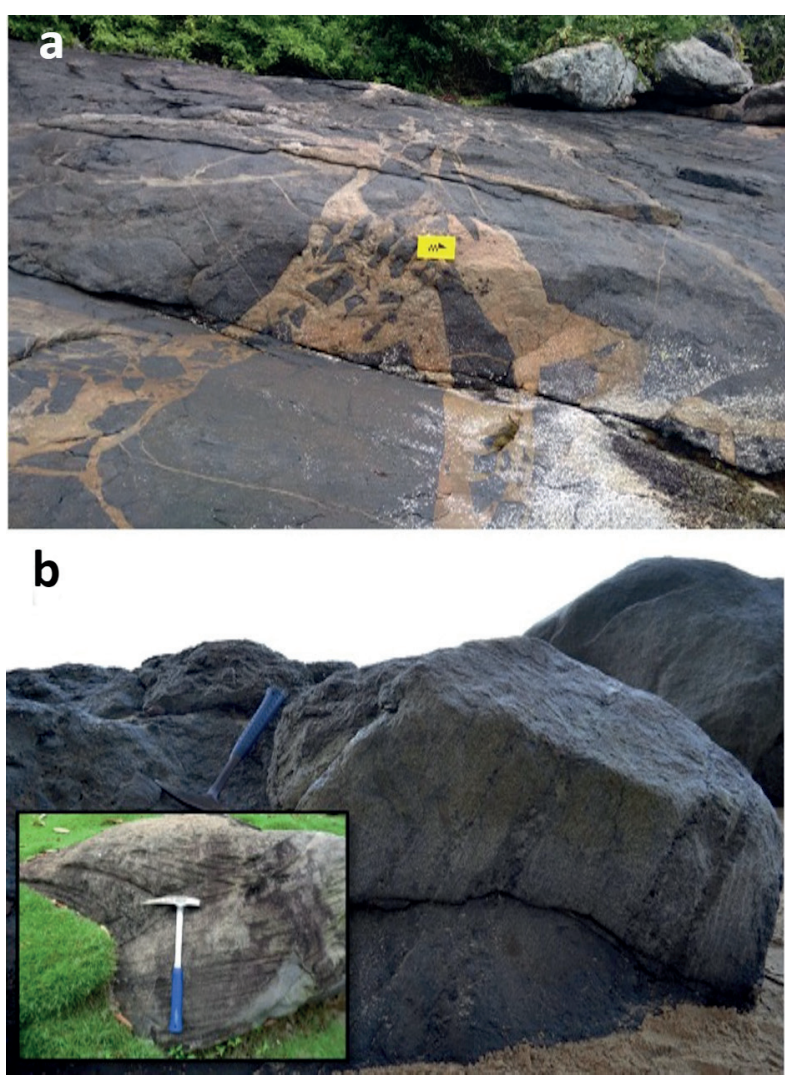

Figure 4 - Representative geosites related to the GF Late Cretaceous Alkaline Magmatism. Geosite "Contact relationships between alkaline rocks of Ilhabela". a) Syenite and gabbro in the Jabaquara Beach. Photo: M. Timich; b) Magmatic compositional layering in cumulate gabbro in Pacuíba Beach. In the detail, "cross bedding" layering (Photo: F. Rodrigues).

pocket-beaches. Coastal dynamic processes are represented by rare Pleistocene marine terraces (Figure 5a) and modern sedimentation processes (Figure 5b).

During the Paleogene, the reactivation of older, Precambrian discontinuities under a leftlateral transtensional stress field was responsible for intracontinental rifting and both elevation and subsidence of adjacent blocks (Almeida and Carneiro 1998, Riccomini et al. 2005, Hiruma et al. 2010, Cogné et al. 2013). The lower block is represented by the coastal-margin Santos Basin. The elevated blocks formed the Serra do Mar and Mantiqueira mountain ranges, the first one being 

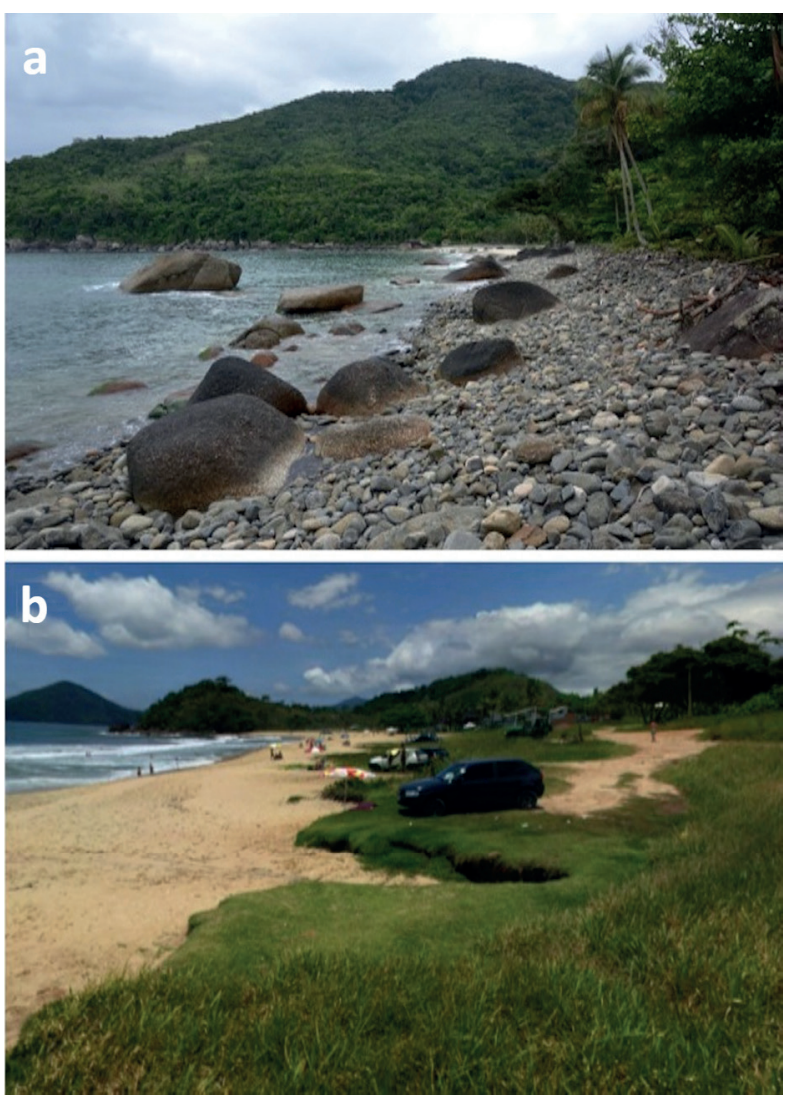

Figure 5 - Representative geosites related to the GF Quaternary Evolution. a) Geosite "Storm-beach sedimentation of Enchovas Beach". An exceptional example of this type of coastal dynamics presenting linear, zoned areas composed of heavy minerals and centimeter-size pebbles deposits; b) Geosite "Pleistocene terraces of Vermelha do Norte Beach". Marine terrace that crops out next to a modern beach, with tectonic influence and which acted as a sandy barrier during Holocene marine transgression. Photo: Google Earth.

the most conspicuous morphological feature of the Southeastern coast of Brazil, forming the structural escarpment at the edge of the Atlantic Plateau. Another remarkable relief feature is related to the alkaline magmatic rocks of Late Cretaceous age and is related to the Cabo Frio Alignment, being represented in the area at Ilhabela and other minor islands (Figure 6a, b).

\section{ASSESSMENT}

Both qualitative and quantitative assessment was performed in order to identify the main
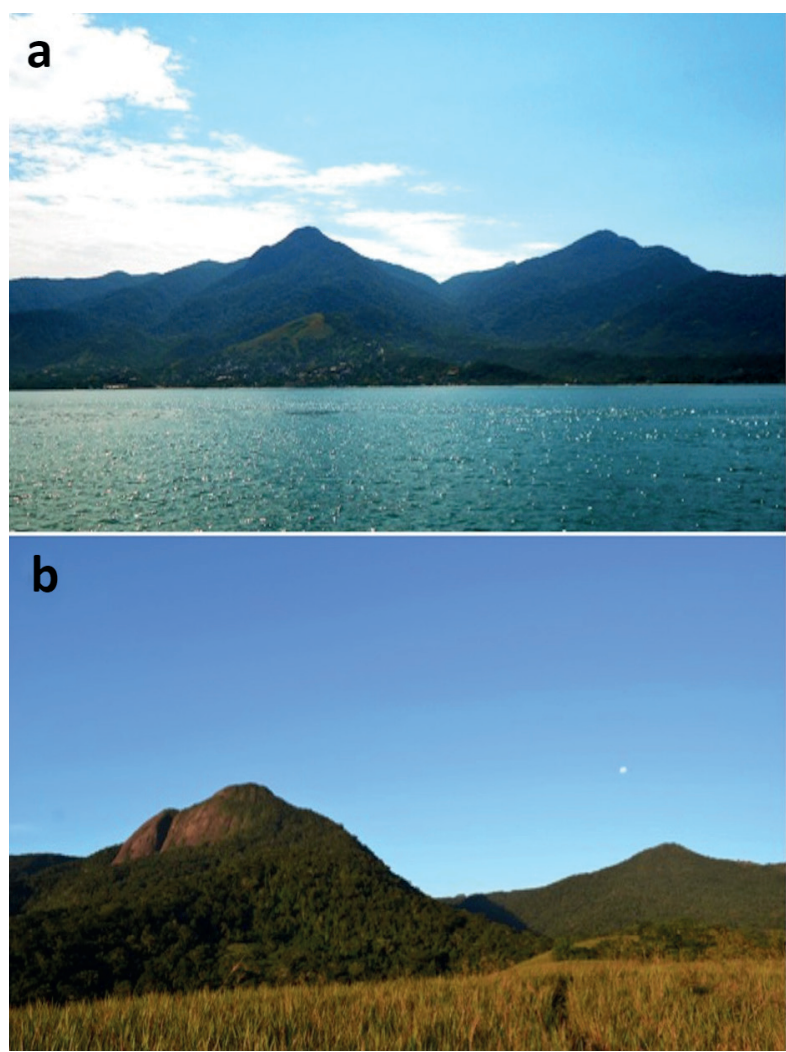

Figure 6 - Representative geosite related to the GF Geomorphology and Landscape Evolution. Geosite "Baepi Peak" - Landform developed on Late Cretaceous alkaline magmatic rocks. a) General view of the relief formed on alkaline batholiths. Baepi Peak on the left side. (Photo: E. Santos); b) Detail of the peak showing E-W fracturing.

characteristics of the geosites. The assessment was carried out following two main lines of investigation:

1) The representativeness of the geosites according to geological history;

2) The priorities for conservation and use of the geosites.

The evaluation of the representativeness of the selected geosites is important because it may guide the actions related both to future research - i.e. their scientific use - and to their interpretation - aiming at popularization of geoscience. The analysis was based on the geological frameworks that, together, tell the geological history of the selected area. The geological frameworks are represented in different 
ways in each town (Figure 7a), a result of a combination of factors such as geological context, geographical conditions and minor anthropic influence. The oldest event recorded by the geosites is related to compressive features such as the folding patterns of the Geosite "Folded granite gneiss of Ponta Aguda Beach", although similar features can also be found locally in the Geosite "Boudins of Camburizinho Tombolo". Recent geological events are represented mainly at the Geosite "Storm-beach sedimentation of Enchovas Beach", which reflects modern coastal processes.

The geological characteristic of the area are fully represented by the analysis of the main geological interests defined for each geosite (Figure $7 b$ ). About $60 \%$ of the geosites present as main interests the following topics: plutonic, tectonic and metamorphism, a fact that reflects the geological nature of the area, composed of crystalline rocks related to collision-type tectonics. Other kinds of interests, such as paleoenvironmental, are also important in the area, especially because of the information they keep about sea level variations.

In order to obtain information on priorities both for conservation and use, two criteria were used to assess the geosites: scientific value and degradation risk. Quantitative evaluation was carried out using GEOSSIT, which is the national application for sites of geological interest developed by the Geological Survey of Brazil - Rocha et al. (2016). The application uses as its basis the works of García-Cortés and Carcavilla (2009) and Brilha (2016).

Figure 8 illustrates the quantitative assessment of the geosites comparing the values for scientific value and degradation risk. The scientific value ranges from 200 to 370 . Seven geosites were classified with international relevance. The main factors that influenced these values were rarity, representativeness and quality of the publications related to the site.

The values obtained for degradation risk range from 45 to 365 . Approximately $25 \%$ of the geosites present very low values $(<100)$, which correspond to those with geomorphological character and those included in protected areas. The geosites presenting low (100-200) or medium risk (200-300) are located at rocky shores and the main factor that controls the results is their accessibility. Six geosites were classified with high degradation risk. As expected, five of these are composed of geologically fragile rocks and sediments. The only exception is the Geosite "Mantle xenoliths of Vermelha do Centro Beach", which corresponds to very small features that could be easily destroyed by anthropic action.

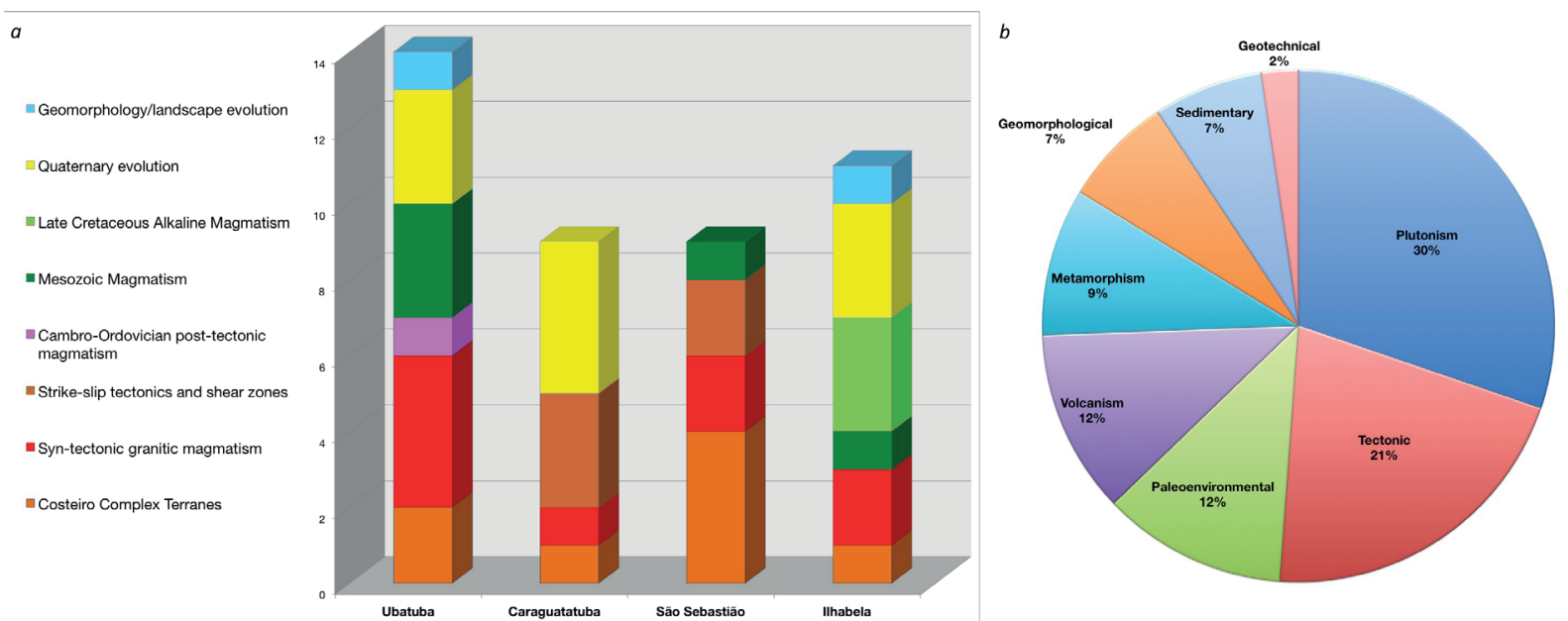

Figure 7 - a) Representativeness of the geological frameworks in each town; b) Main geological interests. 


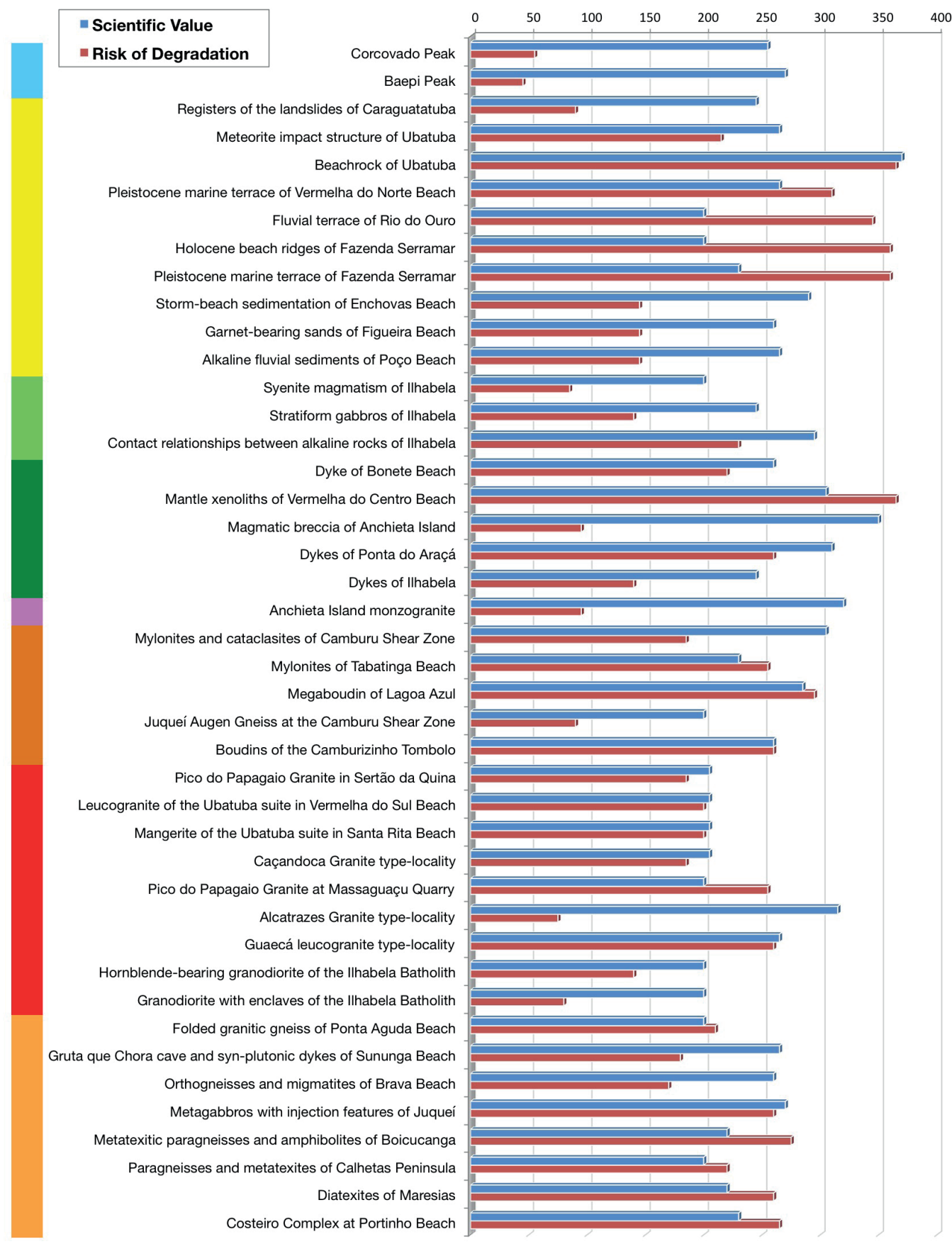

Figure 8 - Quantitative assessment related to the Scientific Value and Degradation Risk. Dashed lines correspond to key values for both criteria. According to GEOSSIT, sites with scientific value above 200 are considered geosites (200 and 300 - national relevance; > 300 - international relevance). Below 200, it would be named a geodiversity site. According to Brilha (2016), degradation risk values can be classified as low (< $200)$, moderate (200-300) and high (>300). 


\section{DISCUSSION}

The successful implementation of geoconservation plans depends on proper interaction between (a) the scientific knowledge, which provides the bases for the recognition of geologically relevant sites; (b) the government authorities, responsible for the management of geoheritage; and (c) interpretation, to promote the dissemination of information to different audiences. The inventories constitute the most reliable way to identify those places that better represent the geological context, and are an essential tool to assess both quality and quantity of sites of geological interest in a given area. The information obtained in these surveys must precede any implementation of geoconservation strategies, which includes either starting a management plan or subsiding government territorial plans. The data obtained in the inventories may, in addition to the obvious scientific contribution, provide subsidies for administrative bodies at different scales to use the geological information in the management of the territory. Moreover, when integrated with other aspects, such as the cultural heritage of the region, they can help to establish sustainable tourism plans that take into account local specificities and contribute to the development of sustainable activities.

Since the prime aim of this project is to use these data in ongoing and future initiatives of nature conservation, popularization of geoscience and sustainable development actions, we evaluate these geosites regarding their representativeness and potential uses, as well as the perspectives for territorial planning and public policies.

\section{RESULTS OF THE REVIEW}

In spite of its proximity to the capital city and to geology universities and research institutes, the northern coast of the State of São Paulo lacks detailed geological mapping, possibly due to the extensive Atlantic Forest cover and to the roughness of the Serra do Mar mountain range. Figure 9 illustrates the sources from where the sites were selected to compose an initial list of potential geosites. The inclusion of geosites that are not properly studied and that were not the focus of official publications is only possible because the original inventories were carried out in restricted areas. Notice that $22 \%$ of the geosites were defined after field works, i.e. constitute new geosites with no references in the literature. A good example of this situation is the geosite "Folded gneiss of Ponta Aguda Beach", which constitute one of the few basement outcrops that show extensive folding. The geosite "Stormbeach sedimentation of Enchovas Beach" can also be included in this scenario and also represents a rare, modern sedimentation feature in the region. Along with field work, some suggestions were taken from local residents, such as the geosite "Boudins of Camburizinho Tombolo", which is an amazing example of the strike-slip tectonics acting on both orthogneisses and mafic intrusions forming $3 \mathrm{D}$, metric boudins. Nearly $60 \%$ of the geosites were nominated by means of literature review and consulting with experts, as expected in a scientificbased inventory. Some items in the potential list constitute traditional tourist attractions and were chosen after qualitative evaluation. In this category we may mention the geosites "Syenite magmatism of Ilhabela", located in Cachoeira do Gato, one of the most visited waterfalls in the island, and "Synplutonic dykes of Gruta que Chora and Sununga Beach", a small and popular cave visited by many tourists. Another geosite that is already used for tourism purposes is the "Mangerite of Ubatuba Suite in Santa Rita Beach", which is also known as the "Bell Stone of Ubatuba", thanks to the metallic sound they emit when hit with a hammer.

The use of the concept of geosite as proposed by Brilha (2016) has revealed to be useful to identify those sites with scientific relevance that should be protected for future research works and those with relevance related to their importance as promoters of sustainable actions and dissemination 


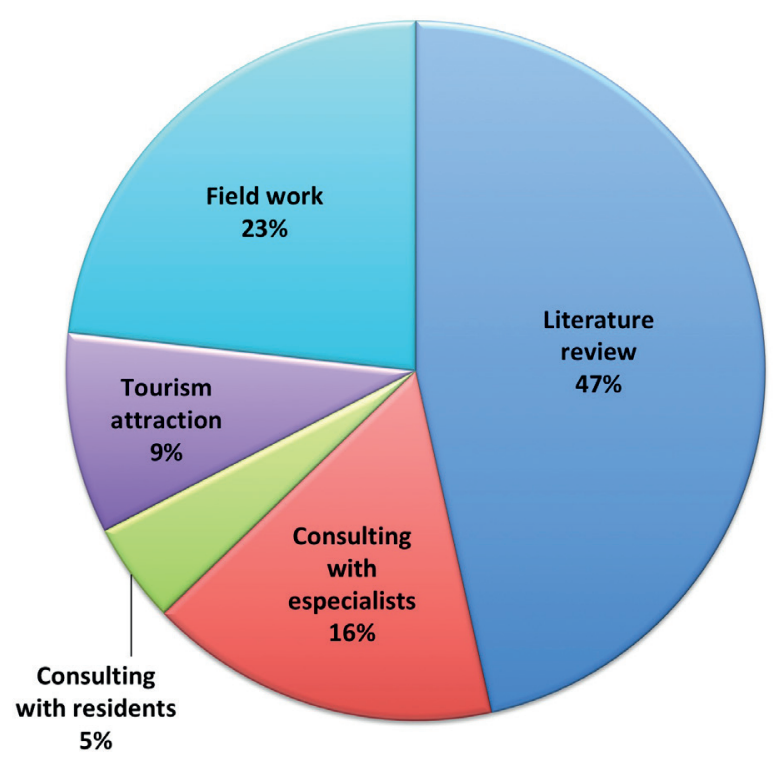

Figure 9 - Sources used to select the geosites.

of geoscience, for example. Geosites such as "Dykes of Ponta do Araçá" and "Mantle xenoliths of Vermelha do Centro Beach" constitute examples of sites that are highly used in field trips for geology students due their representativeness regarding both tholeiitic and alkaline magmatism in the region. An evaluation of the values of tourism and educational potential uses is being carried out, and it will not be discussed in this paper.

Among the 43 geosites, 16 are included in the state inventory (Garcia et al. 2018) and distributed in the following geological frameworks: Precambrian terranes, Shear zones, Granitic rocks, Mesozoic magmatism, Geomorphological units and landforms, and Continental and coastal Neogene and Quaternary evolution. This fact demonstrates the great representativeness of the selected geosites. Also, new geosites such as "Mangerite of Ubatuba Suite in Santa Rita Beach" or "Contact relationships between alkaline rocks of Ilhabela", both defined in the present work, are good candidates to be included in the state inventory, either to replace another one with similar characteristics or because they record a part of the national and/or regional geological history not yet represented.

\section{LEGAL ASPECTS AND CONSERVATION OF GEOSITES}

Since 1937, with the creation of the Itatiaia National Park, significant advances in environmental protection policies have been occurring in Brazil, which include an entire chapter dedicated to the theme in the 1988 constitution, and various environmental crimes and environmental management laws (Pereira et al. 2008, Ferreira 2016). Most of these laws, however, are focused on biodiversity management. Ferreira (2016) argues that in addition to the Decree-Law 25/1937, related with the Protection of Historical Heritage, there are specific laws that deal with the paleontological and speleological heritage. However, the advance in the protection of geological heritage is greatly complicated by the lack of geological knowledge and of adequate research that allow the recognition of national geodiversity and geological heritage. Similar to archaeological or biological heritage, sites of geological interest can and should be included in territorial planning, thus promoting the development of adequate laws to protect geological heritage. Moreover, the inclusion of geoheritage in plans that deal with nature conservation and the recognition of geodiversity as an integral part of the natural environment is fundamental for the maintenance of ecosystems and in modern, political issues such as climate change (Gray et al. 2013).

In this sense, the assessment of the legal situation of the geosites is fundamental. Among the selected geosites, 9 are in protected areas: 3 in Ilhabela State Park, 2 in Anchieta Island State Park, 3 in Serra do Mar State Park and 1 in Tupinambás Ecological Station. Other 3 geosites are located in private domains, and the great majority (30) is located in public areas, being 25 in the so-called Navy Lands, one of the assets of the Federal Government (Figure 10a). These areas correspond to a 33-meters strip from the Line of Average High Tide (which considers the maximum 
tides of the year 1831) towards the mainland or the interior of the coastal islands with headquarters of the municipality. In addition to the areas along the coast, riverbanks and lagoons that are influenced by tides are also included.

The size of the geosite also plays an important role in its conservation. In this sense, the practical approach described by Fuertes-Gutiérrez and Fernández-Martínez (2010), which classified the geosites on the Leon Province in five typologies, can be useful to evaluate the situation of each site (Figure 10b). The geomorphological geosites "Corcovado Peak" and "Baepi Peak" were classified as areas, although they are also used as viewpoints. This approach was preferred due to the specific characteristics of viewpoints, in which the relevant geological features are included in the normally large areas that constitute the "view", and not in the point that serves as an observatory (normally the place from where the best view is obtained). This makes their assessment and management quite confusing and difficult. On the other extreme are the majority of the geosites, classified as points (i.e., less than 1 ha). Three of the geosites are classified as sections: "Contact relationships between alkaline rocks of Ilhabela" - 3 km, "Dykes of Ponta do Araçá" 300 meters - and "Costeiro Complex at Portinho Beach" - 100 meters. Especially for the first one of them, we understand that such a large geosite may be a barrier for conservation. However, this section is composed of important and rare records of the alkaline magmatism in Ilhabela, which includes, from NW to SE: i) Boulders and blocks of cumulate gabbros at the Pacuíba Beach that show unique magmatic structures; ii) Contact relationships between mafic and syenitic alkaline rocks; and iii) Syenite body (Lima 2001, Timich et al. 2016). The northwestern part of the geosite (Pacuíba Beach) is already used for educational purposes for Geology students. For these reasons, we believe it should be included in its totality.
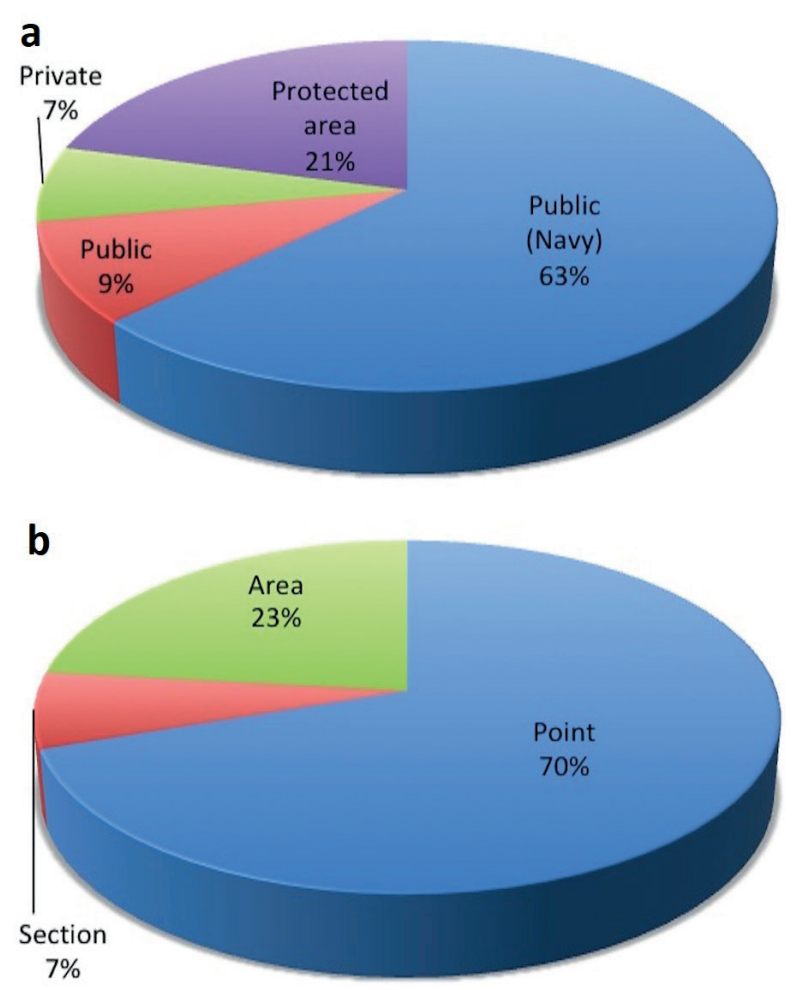

Figure 10 - Assessment of the geosites. a) Relative magnitude of the geosites in relation to the ownership regime; b) Relative magnitude of the geosites in relation to typology in the sense of Fuertes-Gutiérrez and Fernández-Martínez (2010).

Examples of sites in the State of São Paulo where the scientific use is currently complicated or even impossible mainly due to an intense urban development are shown in Garcia et al. (2018) and Reverte et al. (in press). In the coastal region, management may be difficult due to illegal constructions and big enterprises that are common in the coast of Brazil. In the area under investigation, the population has doubled in the last decade (IBGE 2018) due to different reasons, from the construction of a pipeline and a natural gas treatment unit, to the expansion of the main highway linking the coast to the consumer markets, as well as the prospect of expansion of the São Sebastião Harbor. Particularly, the expansion plan includes the construction of a platform that will cover the Araçá Mangrove, in an enterprise whose completion will directly affect one of the 
most significant geosites in the region, the "Dykes of Ponta do Araçá". In this geosite, about twenty dykes of distinct compositions are distributed along 300 meters along the coast, showing different interactions that hold important information about the stress regimes and the volcanic activities during the opening of the South Atlantic Ocean.

Due to the large and rapid population growth, issues such as illegal occupation of forest areas, slopes with landslide risks and riverbanks became very common and some potential geosites were definitely lost. This is especially true for a set of very fragile, sedimentary deposits studied by Souza $(1990,1992)$ and that constitute complete records of important sea-level variations during the Holocene and the Pleistocene that could be used as scientific material and as tools for environmental education. One of these sites was already destroyed by excessive, unplanned urbanization, and two others (the geosites "Holocene beach ridges of Fazenda Serramar" and "Pleistocene marine terrace of Fazenda Serramar") are in extreme danger due to the new Economic-Ecological Zoning for the region, which intends to turn part of the area into an industrial complex (State Decree n 62.913, 08/11/2017).

\section{PERSPECTIVES FOR SUSTAINABLE USE OF GEOSITES}

Since the beginning of geoheritage inventories in the region, many geoconservation actions have been carried out. These actions include the study of the relationship between natural and cultural heritage, the implementation of interpretive panels that convey local geological history, social learning involving participatory methodologies as tools to elaborate geoconservation strategies, confection of workbooks with educational activities based on local geological materials and landscapes, interpretation of the geology along ecotourism trails, and geosciences courses for environmental guides (Garcia et al. 2017). A geotourism mapguide built on the basis of the inventoried geosites and geodiversity sites, also including sites of built heritage, is also being elaborated (Arruda 2017).

However, up until now, these actions have been carried out with little participation of local and regional actors, such as authorities and government, members of social organizations, and legal institutions that deal with conservation, among others. This is important because it brings credibility to the management plan that will be able to include social and economic needs of local populations, as well as protection of the landscape in which they live, and conservation of their cultural identity. In this regard, one of the main challenges of this survey is to work effectively as a practical basis from where political decisions can rely on.

\section{CONCLUSIONS}

The integration and revision of previous local inventories in the northern coast of the State of São Paulo resulted in 43 geosites, distributed in eight geological frameworks that tell the geological history of the area since the Neoproterozoic to the recent, covering about a 700 Ma timespan.

Of the 43 geosites, 16 are included in the State of São Paulo inventory, which reinforces their representativeness as record of regional geological history. With the exception of the Geosite "Alcatrazes Granite type-locality", all the geosites classified as internationally relevant are included in the State inventory and are potential candidates to be included in a national inventory. In this sense, the quantitative assessment proved to be effective in selecting the most representative ones. Surprisingly, although the inventories have been made in town-based manner, even within the same geological framework the geosites present unique features. When taken as a whole, the set of geosites are able to tell many details about each event they represent. Therefore, with the exception of a few very fragile geosites and those with low tourism 
or educational use, they can serve as a basis for the elaboration of local strategies of sustainable tourism in the region.

Taking these examples into account, we believe that the detailed results obtained in the present inventory constitute a precious instrument to direct the decisions related to the conservation and use of this abiotic part of nature in the region. The sites of geological interest may serve both for future research - in the sense that we have also identified the "lacks" on the geological record - and as alternative, new natural sites for which innovative activities and uses can be discovered. Moreover, being a systematic inventory that follows the main principles of the Global Geosites Project, it may contribute to its original objectives of recognizing and managing globally relevant sites (Wimbledon et al. 1996, 1999, Díaz-Martínez et al. 2016), such as the recently approved Geoheritage Map of South America, which will be coordinated by the Geological Survey of Brazil.

The next steps on this project include the integration of data obtained from ongoing geosites and geodiversity sites surveys in the whole coastal region of São Paulo, as well as other information, to built a wide, solid foundation for a future Strategy and Action Plan for Geodiversity in the region.

\section{ACKNOWLEDGMENTS}

To the Fundação de Amparo à Pesquisa do Estado de São Paulo (FAPESP) - Processes 2011/17261-6 and 2016/18652-2 - and to the Dean's Office for Research of the University of São Paulo, by the Program of Incentive to Research that allowed the creation of the Center for Research Support on Geological Heritage and Geotourism. To E. DíazMartínez for his contribution to clarify the text. We also thank the staff of Serra do Mar (Picinguaba, Caraguatatuba and São Sebastião), Ilhabela and Ilha Anchieta State Parks for their valuable help during field work.

\section{AUTHOR CONTRIBUTIONS}

MGM Garcia - Inventory, assessment and discussions;

EA Del Lama - Discussions and characterization of geosites;

L Martins - Geological context and characterization of geosites;

CEM Mazoca - Discussion and images;

CLM Bourotte - Discussion and geosites data.

\section{REFERENCES}

ALEXANDROWICZ Z AND KOZLOWSKI S. 1999. From selected geosites to geodiversity conservation - Polish example of modern framework. In: Barettino D, Vallejo M and Gallego E (Eds), Towards the balanced management and conservation of the geological heritage in the new millenium. Sociedad Geológica de España, Madrid, Spain, p. $40-44$.

ALMEIDA FFM. 1969. Diferenciação tectônica da plataforma brasileira. Anais do XXIII Congr Bras Geol, p. 29-46.

ALMEIDA FFM. 1983. Relações tectônicas das rochas alcalinas mesozoicas da região meridional da Plataforma Sul-Americana. Braz J Geol 13(3): 139-158.

ALMEIDA FFM AND CARNEIRO CDR. 1998. Origem e evolução da Serra do Mar. 2008. Braz J Geol 28(2): 135150.

ALMEIDA FFM, CARNEIRO CDR AND MIZUSAKI AMP. 1996. Correlação do magmatismo das bacias da margem continental com o das áreas emersas adjacentes. Braz $\mathrm{J}$ Geol 23: 125-138.

ALVES A, JANASI V, CAMPOS NETO MC, HEAMAN LM AND SIMONETTI A. 2013. U-Pb geochronology of the granite magmatism in the Embu Terrane: Implications for the evolution of the Central Ribeira Belt, SE Brazil. Precambrian Res 230: 1-12.

ARRUDA KEC. 2017. A Geoconservação como subsídio à gestão territorial sustentável: o mapa geoturístico do litoral norte do estado de São Paulo, 188 p. Tese de Doutorado, Instituto de Geociências, Universidade de São Paulo, São Paulo, Brasil.

ARRUDA KEC, GARCIA MGM AND DEL LAMA EA. 2017a. Inventário e quantificação do patrimônio geológico do município de Caraguatatuba, São Paulo. Rev Geoc UNESP 36(3): 447-462.

ARRUDA KEC, GARCIA MGM AND DEL LAMA EA. $2017 \mathrm{~b}$. Selection method and proposals to the use of geodiversity sites: the case of the north coast of São Paulo State, Brazil. Anuário IGEO 40(3): 24-47. 
AZEVEDO SOBRINHO JM, JANASI VA, SIMONETTI A, HEAMAN LM, SANTORO J AND DINIZ HN. 2011. The Ilha Anchieta Quartz Monzonite: the southernmost expression of $\mathrm{Ca}$. 500 Ma post-collisional magmatism in the Ribeira Belt. An Acad Bras Cienc 83: 891-906.

BARRETO GS. 2012. Geologia e tectônica da porção oeste da Ilha de São Sebastião, SP e a comparação com as áreas continentais adjacentes, 65 p. Monografia, Instituto de Geociências, Universidade de São Paulo, São Paulo, Brasil. (Unpublished).

BARRETO GS. 2016. Geologia dos granitos porfiríticos de Ilhabela - Petrogênese e evolução crustal, 133 p. Dissertação de Mestrado, Instituto de Geociências, Universidade de São Paulo, São Paulo, Brasil. (Unpublished).

BERGER J-P, REYNARD E, BISSIG G, CONSTANDACHE M, DUMAS J, FELBER M, HÄUSELMANN P, JEANNIN P-Y AND SCHNEIDER H. 2008. Révision de la liste des géotopes d'importance nationale: rapport du groupe de travail 2006-2007. Available at: http://igd.unil.ch/projrech/ public/projets/88-1-165.pdf. (Access in 08/01/2018).

BERGER J-P, REYNARD E, CONSTANDACHE M, FELBER M, HÄUSELMANN P, JEANNIN P-Y AND MARTIN S. 2011. Révision de l'inventaire des géotopes suisses: rapport du groupe de travail 2008-2011. Available at: http://igd.unil.ch/projrech/public/projets/88-1-166.pdf. (Access in Jan/2018).

BRILHA J. 2005. Património Geológico e Geoconservação: a Conservação da Natureza na sua Vertente Geológica. Palimage Editores, Viseu, 190 p.

BRILHA J. 2016. Inventory and quantitative assessment of geosites and geodiversity sites: a review. Geoheritage 8: 119-134.

BRILHA J AND PEREIRA P. 2014. Património geológico de Portugal como base para ações de conservação da natureza e ordenamento do território. Com Geol 101(III):12111213.

BRILHA J ET AL. 2010. O inventário nacional do património geológico: abordagem metodológica e resultados. e-Terra, $18(1)$.

BRILHA J, PEREIRA P, PEREIRA D AND HENRIQUES R. 2013. Geossítios de relevância nacional e internacional em Portugal. In: Magalhães MR (Ed), Estrutura Ecológica Nacional, uma proposta de delimitação e regulamentação, p. $169-178$.

BRITO NEVES BB, FUCK RA AND PIMENTEL MM. 2014.

The Brasiliano collage in South America: a review. Braz J Geol 44(3): 493-518.

BUREK C AND POTTER J. 2003. Local Geodiversity Action Plans - Sharing Good Practice Workshop. Eng Nat Res Rep 601, 38 p.

BUREK C AND POTTER J. 2006. Local Geodiversity Action Plans - Setting the context for geological conservation. Eng Nat Res Rep 560, 58 p.
CARCAVILLA L, DURÁN JJ, GARCIA-CORTÉS A AND LÓPEZ-MARTINEZ J. 2009. Geological heritage and geoconservation in Spain: past, present, and future. Geoheritage 1(2-4): 75-91.

CARVALHIDO RJ, BRILHA J AND PEREIRA DI. 2016. Designation of Natural Monuments by the Local Administration: the Example of Viana do Castelo Municipality and its Engagement with Geoconservation (NW Portugal). Geoheritage 8: 279-290.

CENDRERO UCEDA AC. 2000. Patrimonio geológico: diagnóstico, clasificación y valoración. In: SuárezValgrande JP (Ed), Jornadas sobre Património Geológico y Desarrollo Sostenible, Serie Monografías, Ministério de Medio Ambiente de España, p. 23-37.

COGNÉ N, COBBOLD PR, RICCOMINI C AND GALLAGHER K. 2013. Tectonic setting of the Taubaté Basin (Southeastern Brazil): Insights from regional seismic profiles and outcrop data. J S Am Earth Sci 42: 194-204.

COUTINHO JMV. 2008. Dyke swarm of the Paraná triple junction, southern Brazil. Rev Geologia USP Sér Cient 8: 29-52.

DEFRA - DEPARTMENT FOR ENVIRONMENT, FOOD AND RURAL AFFAIRS. 2006. Local Sites: Guidance on their Identification, Selection and Management, England, $30 \mathrm{p}$.

DE WEVER P, ALTERIO I, EGOROFF G, CORNÉE A, BOBROWSKY P, COLLIN G AND PAGE K. 2015. Geoheritage, a national inventory in France. Geoheritage 7(3): 205-247.

DÍAZ-MARTÍNEZ E, BRILHA J, BROCX M, ERIKSTAD L, GARCÍA-CORTÉS A AND WIMBLEDON WAP. 2016. Global Geosites: an active and partially achieved geoheritage inventory initiative, waiting to regain official recognition. In: Cornée A, Egoroff G, de Wever P, Lalanne $A$ and Duranthon F (Eds), Actes du congrès international Les inventaires du géopatrimoine, 22-26 Septembre 2015, Toulouse. Mémoire hors-série de la Société géologique de France 16: 103-108.

ELLIS N. 2011. The Geological Conservation Review (GCR) in Great Britain - Rationale and methods. Proc Geol Assoc 122(3): 353-362.

ENGLISH GEODIVERSITY FORUM. 2014. Geodiversity Charter for England. Available at: http:// www.englishgeodiversity forum.org/Downloads/ Geodiversity\%20Charter\%20 for\%20England.pdf. (Access in 08/01/2018).

FERREIRA MWS. 2016. Enquadramento legal e institucional para a promoção da geoconservação no Brasil e propostas de desenvolvimento, 116 p. Dissertação de Mestrado, Universidade do Minho, Portugal. (Unpublished).

FUERTES-GUTIÉRREZ I AND FERNÁNDEZ-MARTINÉZ E. 2010. Geosites inventory in the Leon Province (Northwestern Spain): a tool to introduce geoheritage into 
regional environmental management. Geoheritage 2(1-2): 57-75.

GARCÍA-CORTÉS A AND CARCAVILLA URQUÍ L. 2009. Documento metodológico para la elaboración del inventario español de lugares de interés geológico (IELIG). Instituto Geológico y Minero de España, Madrid, version $12,61 \mathrm{p}$.

GARCIA-CORTÉS A, RÁBANO I, LOCUTURAJ, BELLIDO F, FERNÁNDEZ-GIANOTTI J, MARTÍN-SERRANO A, QUESADA C, BARNOLAS A AND DURÁN JJ. 2001. First Spanish contribution to the Geosites Project list of the geological frameworks established by consensus. Episodes 24(2): 79-92.

GARCIA MGM. 2012. Gondwana geodiversity and Geological Heritage: examples from the North Coast of São Paulo State, Brazil. Anuário IGEO 35: 101-111.

GARCIA MGM ET AL. 2018. The inventory of geological heritage of the State of São Paulo, Brazil: methodological basis, results and perspectives. Geoheritage 10(2): 239258.

GARCIA MGM, DEL LAMA EA, BOUROTTE C, MAZOCA CEM, BACCI DC AND SANTOS VMN. 2017. Geoheritage inventories as means, not ends: example of the coastal region of São Paulo State, Brazil. Patrimonio Geológico, Gestionando la Parte Abiótica del Patrimonio Natural. Madrid: Instituto Geológico y Minero de España 1: 131-136.

GARDA GM. 1995. Os diques básicos e ultrabásicos da região costeira entre as cidades de São Sebastião e Ubatuba, Estado de São Paulo, 156 p. Tese de Doutorado, Instituto de Geociências, Universidade de São Paulo, São Paulo, Brasil.

GARDA GM AND SCHORSCHER JHD. 1996. Os diques costeiros básicos e ultramáficos adjacentes ao canal de São Sebastião (litoral norte do estado de São Paulo). Rev IG São Paulo 17: 7-31.

GRAY M, GORDON JEAND BROWN EJ. 2013. Geodiversity and the ecosystem approach: the contribution of geoscience in delivering integrated environmental management. Proc Geol Assoc 124: 659-673.

HEILBRON M, PEDROSA-SOARES AC, CAMPOS NETO MC, SILVA LC, TROUW RAJ AND JANASI VA. 2004. Província Mantiqueira. In: Mantesso-Neto et al. (Org), Geologia do Continente Sul-Americano - Evolução da Obra de Fernando Flávio Marques de Almeida, p. 203-234.

HEILBRON M, RIBEIRO A, VALERIANO CM, PACIULLO FV, ALMEIDA JCH, TROUW RAJ, TUPINAMBÁ M AND EIRADO SILVA LG. 2017. The Ribeira Belt. In: Heilbron M, Cordani U and Alkmim F (Eds), São Francisco Craton, Eastern Brazil: Tectonic Genealogy of a Miniature Continent. Regional Geology Reviews. Springer, p. 277302.
HEILBRON M, VALERIANO CM, TASSINARI CCG, ALMEIDA JCH, TUPINAMBA M, SIGA JR O AND TROUW RAJ. 2008. Correlation of Neoproterozoic terranes between the Ribeira Belt, SE Brazil and its African counterpart: comparative tectonic evolution and open questions. In: Pankhurst RJ, Trouw RAJ, Brito Neves $\mathrm{BB}$ and De Wit MJ (Eds), West Gondwana: Pre-Cenozoic Correlations Across the South Atlantic Region. London: Geological Society, Special Publications, 294: 211-238.

HENRIQUES MH, REIS RP, BRILHA J AND MOTA T. 2011. Geoconservation as an Emerging Geoscience. Geoheritage 3: 117-128.

HIRUMA ST, RICCOMINI C, MODENESI-GAUTTIERI MC, HACKSPACHER PC, HADLER NETO JC AND FRANCO-MAGALHÃES AOB. 2010. Denudation history of the Bocaina Plateau, Serra do Mar, Southeastern Brazil: Relationships with Gondwana breakup and passive margin development. Gondwana Res 18: 674-687.

IBGE - INSTITUTO BRASILEIRO DE GEOGRAFIA E ESTATÍSTICA. 2018. Brasil em síntese - Cidades. Available at: https://cidades.ibge.gov.br/. (Access in 11/01/2018).

IGME - INSTITUTO GEOLÓGICO Y MINERO DE ESPAÑA. 2018. Inventario Español de Lugares de Interés Geológico (IELIG). Available at: http://info.igme.es/ielig/. (Access in 11/01/2018).

ISPRA - ISTITUTO SUPERIORE PER LA PROTEZIONE E LA RICERCA AMBIENTALE. 2018. Geositi - Inventario Nazionale dei Geositi italiani. Available at: http://sgi. isprambiente.it/geositiweb/default.aspx?ReturnUrl=\% $2 \mathrm{fg}$ eositiweb\%2f. (Access in 11/01/2018).

JANASI VA, SIGA JR O, SATO K, MACHADO FB, SOARES JUNIOR AV, MAGALHÃES AOBF AND MACHADO AV. 2012. The young guys are in town: a $\sim 500 \mathrm{Ma} \mathrm{U-Pb}$ Shrimp age for the Santos and Guarujá granites extends further south the Ribeira "G5" magmatism. In: $46^{\text {th }}$ Brazilian Geological Congress, Santos.

JANASI VA, VASCONCELLOS ACBC, SIGA JR O, SATO $\mathrm{K}$, MACHADO FB, MARTINS L AND GARCIA MGM. 2015. In situ U-Pb dating and Hf isotope geochemistry of zircons from granites os the Costeiro Domain, SE Brazil: timing and source contrasts with neighboring terranes of the Ribeira Belt. The 8th Hutton Symposium of Granites and Related Rocks. Florianópolis, p. 69.

LIMA GA. 2001. Gabros estratiformes da região norte da Ilha de São Sebastião, SP, 170 p. Dissertação de Mestrado, Instituto de Geociências, Universidade de São Paulo, São Paulo, Brasil. (Unpublished).

MAFFRA CQT. 2000. Geologia estrutural do embasamento cristalino na região de São Sebastião, SP: evidências de um domínio transpressivo, 113 p. Dissertação de Mestrado, Instituto de Geociências, Universidade de São Paulo, São Paulo, Brasil. (Unpublished). 
MARTÍN-DUQUE JF, CABALLERO GARCÍA J AND CARCAVILLA URQUÍ L. 2012. Geoheritage information for Geoconservation and Geotourism through the categorization of landforms in a karstic landscape. A case Study from Covalagua and Las Tuerces (Palencia, Spain). Geoheritage 4(1-2): 93-108.

MARTINS L, GARCIA MGM AND REVERTE FC. 2014. Geologia do Arquipélago de Alcatrazes, litoral norte do estado de São Paulo. In: $47^{\text {th }}$ Congresso Brasileiro de Geologica, Salvador.

MEIRA VT. 2014. Evolução tectono-metamórfica neoproterozoica dos complexos Embu e Costeiro no contexto de formação do Gondwana Ocidental (leste do estado de São Paulo), 266 p. Tese de Doutorado, Instituto de Geociências, Universidade de São Paulo, São Paulo, Brasil.

MEIRA VT, GARCÍA-CASCO A, JULIANI C, ALMEIDA RP AND SCHORSCHER JHD. 2015. The role of intracontinental deformation in supercontinent assembly: insights from the Ribeira Belt, Southeastern Brazil (Neoproterozoic West Gondwana). Terra Nova 27: 206217.

MOHRIAK W, NEMCOK M AND ENCISO G. 2008. South Atlantic divergent margin evolution: rift-border uplift and salt tectonics in the basins of SE Brazil. Geological Society, London, Special Publications 294(1): 365-398.

MUCIVUNA VC, GARCIA MGM AND DEL LAMA EA. 2015. A seleção de geossítios no inventário do município de Bertioga - SP: critérios e metodologias. In: III Simpósio Brasileiro de Patrimônio Geológico, Lençóis - BA. Anais digitais.

NATURE CONSERVATION COUNCIL. 1990. Earth Science Conservation in Great Britain - a Strategy, p. 1-84.

NETO DE CARVALHO C, RODRIGUES JC AND METODIEV D. 2009. Inventário do património geológico do concelho de Vila Velha de Ródão: contributo para a caracterização do Geopark Naturtejo da Meseta Meridional. Açafa On-line 2: 1-53.

OMS O, CLIMENT F, PARCERISA D, MATA-PERELLÓ JM AND POCH J. 2012. The geological and paleontological heritage of Manresa municipality (Catalonia, Spain). IN: XIII Congreso Internacional Sobre Patrimonio Geológico Y Minero, p. 393-400.

PELLITERO R, GONZÁLEZ-AMUCHASTEGUI MJ, RUIZFLAÑO P AND SERRANO E. 2011. Geodiversity and geomorphosite assessment applied to a natural protected area: the Ebro and Rudron Gorges Natural Park (Spain). Geoheritage 3: 163-174.

PEREIRA RF, BRILHA J AND MARTINEZ JE. 2008. Proposta de enquadramento da geoconservação na legislação ambiental brasileira. Mem Not 3: 491-494.

PERROTTA MM, SALVADOR ED, LOPES RC, D'AGOSTINHO LZ, PERUFFO N, GOMES SD, SACHS
LLB, MEIRA VT, GARCIA MGM AND LACERDA

FILHO JV. 2005. Mapa geológico do estado de São Paulo, escala 1:750.000. Programa levantamentos geológicos básicos do Brasil, CPRM, São Paulo.

PIRES AS. 2017. Mapeamento geológico e estrutural das suítes graníticas e charnockítica na região $\mathrm{SW}$ de Ubatuba (SP), 108 p. Dissertação de Mestrado, Instituto de Geociências, Universidade de São Paulo, São Paulo, Brasil. (Unpublished).

PROCHOROFF R. 2014. O patrimônio geológico de IlhabelaSP: estratégias de geoconservação, 176 p. Dissertação de Mestrado, Instituto de Geociências, Universidade de São Paulo, São Paulo, Brasil. (Unpublished).

REVERTE FC. 2014. Avaliação da Geodiversidade em São Sebastião - SP, como patrimônio geológico, 208 p. Dissertação de Mestrado, Instituto de Geociências, Universidade de São Paulo, São Paulo, Brasil. (Unpublished).

REVERTE FC AND GARCIA MGM. 2016a. The geological heritage of São Sebastião, SP: Inventory and potential use of geosites with scientific value. Rev Geoc UNESP 35(4): 495-511.

REVERTE FC AND GARCIA MGM. 2016b. Quantitative Evaluation of Geological Heritage: Application to Geosites of São Sebastião, Northern Coast of São Paulo. Anuário IGEO 39: 43-56.

REVERTE FC, GARCIA MGM AND BRILHA J. IN PRESS. Inventário como instrumento de gestão e preservação da memória geológica: exemplo dos geossítios vulneráveis da Bacia de Taubaté - SP. Pesquisas em Geociências.

REYNARD E. 2013. The revision of the Swiss Inventory of Geosites (2006-2012). Geophysical Research Abstracts, vol. 15, EGU: 3568.

RICCOMINI C, VELÁZQUEZ VF AND GOMES CB. 2005. Tectonic controls of the Mesozoic and Cenozoic alkaline magmatism in central-southeastern Brazilian Platform. In: Gomes CB and Comin-Chiaramonti P (Eds), Mesozoic to Cenozoic Alkaline Magmatism in the Brazilian Platform. EDUSP-FAPESP, p. 31-55.

ROCHA AJD, LIMA E AND SCHOBBENHAUS C. 2016. Aplicativo Geossit: nova versão. In: $48^{\circ}$ Congresso Brasileiro de Geologia. Available at: http://sbg.sitepessoal. com/anais48cbg/st22/ID6389_111446_52_Aplicativo_ Geossit.pdf. (Access in 08/01/2018).

ROCHA D. 2008. Inventariação, caracterização e avaliação do património geológico do Concelho de Arouca, 212 p. Dissertação de Mestrado, Universidade do Minho, Portugal. (Unpublished).

RODRIGUES FV. 2018. Estudo da geodiversidade da região norte da Ilha de São Sebastião (SP): uma proposta de mapeamento geoambiental aplicado à estratégia de geoconservação, 241 p. Tese de Doutorado, Instituto 
de Geociências e Ciências Exatas, Rio Claro, Brasil. (Unpublished).

ROMÃO RMM AND GARCIA MGM. 2017. Iniciativas de inventário e quantificação do patrimônio geológico no Brasil: panorama atual. Anuário IGEO 40(2): 250-265.

SANTOS PLA. 2014. Patrimônio geológico em Áreas de Proteção Ambiental: Ubatuba - SP, 207 p. Dissertação de Mestrado, Instituto de Geociências, Universidade de São Paulo, São Paulo, Brasil. (Unpublished).

SCHMITT RS, TROUW RAJ, VAN SCHMUS WR AND PIMENTEL MM. 2004. Late amalgamation in the central part of Western Gondwana: new geochronological data and the characterization of a Cambrian collision orogeny in the Ribeira Belt (SE Brazil). Precambrian Res 133: 2961.

SCOTTISH GEODIVERSITY FORUM. 2013. Scotland's Geodiversity Charter. Available at: https:// scottishgeodiversityforum.org/charter/. (Access in 08/01/2018).

SOUZA CRG. 1990. Considerações sobre os Processos Sedimentares Quaternários e Atuais na Região de Caraguatatuba, Litoral Norte do Estado de São Paulo, 314 p. Dissertação de Mestrado, Instituto Oceanográfico, Universidade de São Paulo, São Paulo, Brasil. (Unpublished).

SOUZA CRG. 1992. Considerações sobre a origem de um depósito marinho pleistocênico no litoral norte do Estado de São Paulo. Boletim do IG-USP, Série Científica 23: 43-54.

SOUZA CRG. 2013. The Ubatuba beachrock (state of São Paulo, Brazil): a new evidence of a mid-Holocene negative sea-level. In: Abstracts 8th IAG congress, Paris, p. 26-30.

SUGUIO K AND MARTIN L. 1978. Quaternary marine formations of the state of São Paulo and southern Rio de Janeiro. In: International Symposium on Coastal Evolution
Quaternary, São Paulo, IGCP/IGUSP/SBG. Special Publication... São Paulo, 55 p.

TASSINARI CCG, MUNHÁ JMU, BENTO DOS SANTOS TM, DIAS NETO CM, PALACIOS T AND FONSECA PE. 2008. SHRIMP U-Pb Zircon Geochronology, Rb$\mathrm{Sr}$ and Sm-Nd Isotope Geochemistry of Ribeira Belt Charnockites and Associated Granitoids. Abstracts of the VI South American Symposium on Isotope Geology, Bariloche.

TIMICH M, AZZONE RG, ENRICH GER AND SILVAFILHO SVM. 2016. Relações de contato entre rochas alcalinas máficas e sieníticas na Praia do Jabaquara, setor norte da Ilha de São Sebastião, SP. $48^{\circ}$. Congresso Brasileiro de Geologia. Anais digitais.

TUPINAMBÁ M, HEILBRON M, VALERIANO C, PORTO JR R, BLANCO DE DIOS F, MACHADO N, EIRADO SILVA LG AND ALMEIDA JCH. 2012. Juvenile contribution of the Neoproterozoic Rio Negro Magmatic Arc (Ribeira Belt, Brazil): Implications for Western Gondwana Amalgamation. Gond Res 21: 422-438.

VILAS BOAS M, NETO DE CARVALHO C, RODRIGUES JC AND VALENTE A. 2015. Património Geológico de Penamacor: inventário de Geossítios e propostas para a sua valorização. Açafa Online 10: 23-72.

WIMBLEDON WAP. 1996. Geosites - a new IUGS initiative. Episodes 19: 87-88.

WIMBLEDON WAP. 2011. Geosites - a mechanism for protection, integrating national and international valuation of heritage sites. Geologia dell'Ambiente, Supplemento 2: $13-25$.

WIMBLEDON WAP, BENTON MJ, BEVINS RE, BLACK GP, BRIDGLAND DR, CLEAL CJ, COOPER RG AND MAY VJ. 1995. The development of a methodology for the selection of British Geological sites for geoconservation: part 1. Mod Geol 20: 159-202. 